History and Industrial Civilisation 


\section{History and \\ Industrial Civilisation}

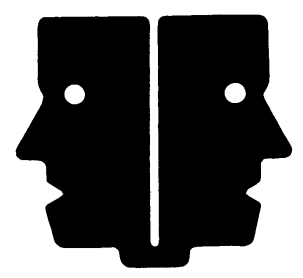

R A BUCHANAN

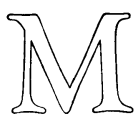


(C) R. A. Buchanan 1979

Softcover reprint of the hardcover 1st edition 1979 978-0-333-26077-7

All rights reserved. No part of this publication may be reproduced or transmitted, in any form or by any means, without permission.

First published 1979 by

THE MACMILLAN PRESS LTD

London and Basingstoke

Associated companies in Delhi Dublin

Hong Kong Johannesburg Lagos Melbourne

New York Singapore and Tokyo

\section{British Library Catologuing in Publication Data}

Buchanan, Robert Angus

History and industrial civilisation.

1. Civilization - History

I. Title

909

CB68

ISBN 978-0-333-26078-4

DOI 10.1007/978-1-349-16128-7

This book is sold subject to the standard conditions of the Net Book Agreement.

The paperback edition of this book is sold subject to the condition that it shall not, by way of trade or otherwise, be lent, resold, hired out, or otherwise circulated without the publisher's prior consent in any form of binding or cover other than that in which it is published and without a similar condition including this condition being imposed on the subsequent purchaser. 


\section{Contents}

PREFACE vii

1 Introduction 1

2 Society and Civilisation 19

3 The City and the Individual 33

4 The Rise of Western Civilisation 47

5 The Mainspring of European Growth 62

6 The Promethean Revolution 82

7 The Ascendancy of Europe 102

8 The Twentieth-century World 121

9 The Lessons of History 146

10 The Prospects of Industrial Civilisation 163

REFERENCES AND FURTHER READING 182

INDEX 193 


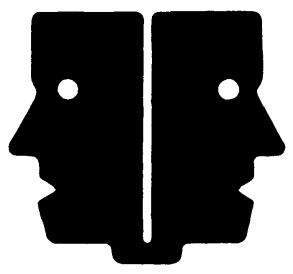

Iron sharpeneth iron; so a man sharpeneth the countenance of his friend. PROVERBS 27 v. 17.

Brian Geeson, Peter Olley, Bernard Israel, David Warren, Ian Livingstone, Glen Fallows, Sam Taylor, Maurice Marks, Peter Craddock, Jack Cheesman, David Johnson, T S Hamilton, A L Jones, F R Campbell, Ernst Hardy, Eric Waite, John Thomson, Christopher Hughes Smith, Mabel Mitchell, Charlie Woods, Neville Nicholson, Roy Pass, Tony Church, Bill Coates, John Punter, Mike Brookbank, Eddie Wignall, Gerald Manners, Margaret Davies, Hazel Holland, Peter Watkins, Peter Hall, John Vaizey, Tony Cross, Geoff Stokell, Oliver MacDonagh, Dick Gooderson, E E Rich, Alan Wilkinson, Garry Runciman, J J Knonshiel, John Herklotts, Richard Acland, Stanley Booth-Clibborn, Ted Wickham, Alan Ecclestone, George Macleod, Donald Soper, John Groser, Ethel Upton, H L Beales, Bill Hamling, Edwin Barker, Frank de Jonge, Alfred Jowett, Theo Barker, O R MacGregor, John Wayland, Johnny Cavanagh, Eric Moonman, Gerald Walters, Edward Horesh, Martin Swainston, Tony Benn, John Ollis, Julie Ollis, Mark Smith, Rita Hinden, Betty Vernon, Margaret Cole, John Lamble, John Cooper, George Wilkinson, John Totterdill, Ken Williams, Jane Williams, Adrian Wright, Mel Kranzberg, Gene Ferguson, Brooke Hindle, Jan DeArmond, Neil Cossons, Arthur Elton, Tom Rolt, George Watkins, John Butt, Michael Drake, Harry Armytage, John Harris, Keith Falconer, Rex Wailes, Rupert Hall, Margaret Weston, Paul Wilson, Brenda Buchanan. 


\section{Preface}

History, on any definition, is about the past, and to many people the past is dead and irrelevant to the concerns of the present and the future. It is the purpose of this book to demonstrate that, far from being dead and irrelevant, the past contains all the most valuable experience we can acquire to help us to understand contemporary problems, and that the acquisition and application of such experience is a valid and, indeed, an indispensable exercise. It is the exercise of Applied History, and this book is concerned with exploring the possibilities of using knowledge of the past in achieving an understanding of the complex Industrial Civilisation of which we are all members.

The plan of the book is quite simple. It consists of a conceptual and analytical discussion of some of the major themes in the emergence of modern Industrial Civilisation, placed in the context of a chronological treatment of this development from the earliest civilised societies to the present day. Then, in the last two chapters, an attempt is made to assess the lessons of history and to outline projections derived from the study of history which indicate possible and even probable evolutionary patterns in the immediate and more remote future. The treatment is discursive rather than exhaustive: macro-historical rather than a succession of detailed micro-studies. The distinctive quality of this approach is its concentration on the single integrating objective of achieving an understanding of the dominant characteristics of our civilisation.

It would be unreasonable to expect the reader to agree with every aspect of the interpretation presented in these pages. Inevitably, the interpretation is a personal statement. Yet it is one arising out of a shared situation, so that I hope that I succeed in providing scope even for the reader who differs most widely from me to sharpen the focus of his own point of view. Now, as never before, no man is an 
island, and as we all share in common the problems of living in the modern world, it should be possible to arrive at a common understanding about the nature of these problems and the solutions to them. I hope, therefore, that this book will prove helpful both to those who ask: 'What is the use of studying history?' and, more generally, to those citizens of contemporary world society who seriously ask the question: 'Where are we going?'

The book has taken a long time to arrive at its present form, and I am deeply conscious of many debts incurred in the process of its gestation. I have tried to acknowledge my obligations to personal friends and acquaintances in the dedicatory list. Sadly, too many of those named are no longer able to receive my thanks. Others may wonder at - or be indignant at - their inclusion, and if so I can only say that I am aware of having benefited from my contact with them, although I would not care to particularise the nature of this benefit in all cases. Still, to all these I am grateful, as I am also to Mrs Judith Burchell and Miss Joanna Valentine for their help in preparing the typescript. And finally, my thanks to my wife, for her inspiration, support, and constructive criticism over the last thirty years. 